\title{
EDLP and Private Labels: Unes Strategic Levers to Look Forward ${ }^{*}$
}

\author{
Paolo Paronzini**
}

\begin{abstract}
U2 Supermarket and private label products are the main strategic levers that qualify the development of UNES. U2 is a "countercurrent Supermarket" that combine the Every Day Low Price (EDLP) business model with the offer of a wide range of private label products often subject to innovation in order to satisfy changeable customers' needs.
\end{abstract}

Keywords: Supermarkets; Over-supply; Private Label; Market-Driven Management; Temporary Store; Global Markets; Online Sales; Alliances; Global Competition

\section{Unes Company History}

Unes was born in Milan in 1967 by the intuition of seven small retailers, who joined to develop a network of small stores, a great innovation for the time.

Afterwards other local entrepreneurs decide to marry this business idea joining the project with enthusiasm. Designed to meet the changing needs of consumers, neighborhood supermarkets were based on an innovative formula that combined the quality and the assortment of large retailers with the characteristics of proximity stores.

In 2002 Unes is acquired by a great protagonist of modern distribution, the Finiper Group, owned by Marco Brunelli. Entering the group guaranteed Unes a series of successful synergies that allowed it to increase its competition in the retail environment.

The real change took place since 2006 when, with the replacement of Unes management and the nomination of Mario Gasbarrino as CEO, the company decided to question the commercial policy and review its position. U2 Supermercato was born this way, a retail brand developed according to the EDLP philosophy (Every Day Low Price), the first in Italy.

In its 50 years Unes developed through the opening of new stores, also with franchise operators.

Today Unes operates with more than 190 supermarkets, including directs and franchise, in Lombardy, Piedmont and Emilia Romagna.

The company, which counts on a workforce of 2,600 employees, closed the year 2015 with a gross turnover of 923 million.

\footnotetext{
* Invited Article

** Marketing and Communications Director, Unes Supermarkets (paolo.paronzini@unes.it)
} 
Today U2 Supermercato is the business model which the company believes and invests on.

\section{U2 Supermercato: The Countercurrent Brand}

U2 is called the 'countercurrent Supermarket' because doesn't make most of the things that make all the competitors.

With its business model Every Day Low Price, U2 Supermercato combines the quality of Unes supermarkets with a more aggressive price line, and implements different and opposite choices respect to the competitors: not realize promotions, does not print or distribute flyers, it has no loyalty program with points or similar tiles, it lives on word of mouth and customers active reference, and last but not least, has a volume share of private labels in line with European values.

The environment within U2 Supermercato is modern and welcoming, such as to perceive the purchase as a pleasant moment. The departments are organized with great care and attention to detail in order to give to the customers a unique experience; for example, fruit \& vegetables area is structured as a small local market, full of perfumes and colors.

Shelves' layout allows the customer a quick and conscious purchase in fact private labels are always next to the industry brands.

U2 Supermercato has adopted a strategy for enhance and develop its private labels, especially the high range brand Il Viaggiator Goloso, creating dedicated events both within supermarkets than in temporary tailored areas.

\section{Il Viaggiator Goloso: Unes Private Label Top Brand}

Il Viaggiator Goloso is the top private label designed to offer the best Italian specialties carefully selected even to the most refined palates. The range, consisting of over 440 references, covers most of the food categories and allows to travel through the Italian culinary traditions and to discover the most authentic flavors.

In order to strengthen Il Viaggiator Goloso's brand identity, in 2016 Unes joined the twelfth edition of MARCA, the most important Italian event dedicated to private labels, choosing to present only its top line.

Il Viaggiator Goloso achieved excellent results in recent years: in U2 Supermercato private labels share is growing, so much so that in 2015 reached $38.5 \%$ progressive, $6.4 \%$ of which developed by Il Viaggiator Goloso. The turnover developed by il Viaggiator Goloso in 2015 amounted to 34.9 million (+ 26.4\%; vs 2014).

Moreover, in December 2015, and throughout Christmas time, the first Temporary Store dedicated to the brand opened, reflecting the fact that the Viaggiator Goloso has consolidated its brand identity and aspires to become a benchmark in the private label landscape.

The aim of il Viaggiator Goloso Temporary Store was consolidate the identity of the brand and make it a reference point in the world of private labels, releasing it from retail and exhibition dogmas. 
All the customers who visited the Store are a clear indicator of the success of the initiative and evidence that Il Viaggiator Goloso is a brand that can satisfy consumers aware of affordable quality.

\section{Private Label as a Stategic Lever}

Unes believes in private brands as strategic drivers; for this reason, in addition to the top Il Viaggiator Goloso, has developed other three lines.

Il Viaggiator Goloso BIO includes a series of products designed to satisfy the increasingly attention to the quality of the food and all the issues related to nutrition. It affects a market that grows constantly and combines the desire to seek the food excellence and the need to offer organic products.

U! Confronta \& Risparmia is Unes brand Low Cost-High Value; this means that all the products of this line are selected items with guaranteed quality at an affordable price. Quality assurance is a distinctive characteristic of the line, confirming the promise low cost-high value. The offer consists of more than 1000 references in all major categories, with a price positioning that allows savings of up to $50 \%$ compared to the category leader.

ECO U!, eco products designed for personal and home care and laundry. The offer proposes, among others, detergents made from vegetable origin and Presolana water, that has been unpacked in order to save $50,400 \mathrm{KWh}$ of energy required for the packaging and the equivalent of 713 trucks of plastic waste to dispose. The references which make up the line are over 50.

Now, thanks to the partnership with Amazon, U2 Supermercato has reached a new important goal: By Amazon Prime Now Customers can purchase all the products that there are in a U2 store at any time and have them delivered wherever they wish, free in two hours. In this way, even who have not U2 Supermercato near home has access to all products, including Unes Private Labels.

\section{Bibliography}

Brondoni, S.M., \& Musso, F., Ouverture de 'Marketing Channels and Global Markets', Symphonya. Emerging Issues in Management (symphonya.unimib.it), 1, 1-6.

http://dx.doi.org/10.4468/2010.1.01ouverture

Cho, H., \& Fiorito, Susan S., Self-Service Technology in Retailing. The Case of Retail Kiosks, Symphonya. Emerging Issues in Management (symphonya.unimib.it), 1, 43-55.

http://dx.doi.org/10.4468/2010.1.05cho.fiorito

Goldman, A., \& Hino, H. (2005). Supermarkets vs. Traditional Retail Stores: Diagnosing the Barriers to Supermarkets' Market Share Growth in an Ethnic Minority Community, Journal of Retailing and Consumer Services, 12 (4), 273-284.

http://dx.doi.org/10.1016/j.jretconser.2004.10.002

Kale, P., Dyer, J. H., \& Singh, H. (2002). Alliance Capability, Stock Market Response, and Long Term Alliance Success: The Role of the Alliance Function, Strategic Management Journal, 23, 747-767.

http://dx.doi.org/10.1002\%2Fsmj.248 
Lamey, L., Deleersnyder, B., \& Dekimpe, M. G., Steenkamp, Jan-Benedict E.M. (2007). How Business Cycles Contribute to Private-Label Success: Evidence from the United States and Europe, Journal of Marketing, 71 (1), 1-15.

http://dx.doi.org/10.1509/jmkg.71.1.1

Musso, F. (2010). Innovation in Marketing Channels, Symphonya. Emerging Issues in Management (symphonya.unimib.it), 1, 23-42.

http://dx.doi.org/10.4468/2010.1.04musso

Riboldazzi, S. (2005). Global Retailers and Competitive Customer Value, Symphonya. Emerging Issue in Management (symphonya.unimib.it), 2, 77-87.

http://dx.doi.org/10.4468/2005.2.07riboldazzi

Risso, M. (2010). Large Retailers' Financial Services, Symphonya. Emerging Issues in Management (symphonya.unimib.it), 1, 65-75.

http://dx.doi.org/10.4468/2010.1.07risso

Rosenbloom, B. (2010). Six Classic Distribution Paradigms for Global Marketing Channel Strategy, Symphonya. Emerging Issues in Management (symphonya.unimib.it), 1, 7-17.

http://dx.doi.org/10.4468/2010.1.02rosenbloom

Tassinari, V. (2010). Retailers, Frontiers of Innovation and Local Legislative Constraints, Symphonya. Emerging Issues in Management (symphonya.unimib.it), 1, 18-22.

http://dx.doi.org/10.4468/2010.1.03tassinari

Vaidyanathan, R., \& Aggarwal, P. (2000). Strategic Brand Alliances: Implications of Ingredient Branding for National and Private Label Brands, Journal of Product \& Brand Management, 9(4), 214-228.

http://dx.doi.org/10.1108/10610420010344013 